\title{
Getting the Most from the Host: How Pathogens Force Plants to Cooperate in Disease
}

\author{
Sophie Hok, Agnès Attard, and Harald Keller \\ Plant-Oomycete Interaction Group, UMR-Interactions Biotiques et Santé Végétale, INRA1301-CNRS6243-Université \\ Nice-Sophia Antipolis, 06903 Sophia Antipolis, France
}

Submitted 30 April 2010. Accepted 24 June 2010.

Plant diseases caused by pathogenic microorganisms remain a major limitation in many crop production systems. Nonetheless, constitutive and inducible defense mechanisms render most plants inaccessible to pathogens, making disease an exception rather than a common outcome of plantmicrobe interactions. Defense mechanisms and associated pathogen resistance were thus of key interest to many plant pathologists, and many of the molecular mechanisms underlying resistance have been elucidated over the last few decades. In recent years, the analysis of physiological and molecular determinants accounting for successful infection and eventual disease has become a topic of prime scientific interest. The hunt is now on for pathogen effectors subverting the host cell and for the plant compatibility functions manipulated by these effectors. An understanding of the molecular mechanisms underlying successful infection should make it possible to develop new crop protection strategies based on interference with compatibility to prevent disease. This review is addressing plant susceptibility and highlights a number of host processes that have been shown to be induced or subverted to facilitate infection. In particular, we focus on those processes that appear to be manipulated by filamentous fungal and oomycete pathogens.

Plants are continually exposed to pathogenic microorganisms but, in most cases, their constitutive defenses are sufficient to prevent disease. The presence of physical barriers, such as the cuticle and cell walls, and the generation of toxic secondary metabolites are generally sufficient to stall the attempts of a potential aggressor to establish infection. Any pathogen able to breach these constitutive barriers is then confronted with nonself recognition mechanisms, which initiate several layers of the plant immune system. A first layer of plant defense is activated by the perception of conserved microbe-associated molecular patterns (MAMPs) by membrane-bound pattern recognition receptors (Zipfel 2009). MAMP-triggered defense responses are generally sufficient to prevent infection. However, some pathogens produce and secrete virulence factors that either repress or reprogram host cell defense signaling, enabling them to overcome this first layer of the immune response. Most plants have thus evolved a second layer of immune responses, in which resistance $(R)$ gene products recognize the presence or activities of microbial effector molecules. $R$ gene product-mediated recognition triggers extremely strong

Corresponding author: H. Keller; E-mail: keller@ sophia.inra.fr; Telephone: +0033-492386594; Fax: +0033-492386587. defense responses, frequently resulting in a localized form of programmed host cell death known as the hypersensitive response (HR) (Chisholm et al. 2006). This 'arms race' between plants and pathogens, in which the evolution of new defenses is matched by the evolution of new ways to overcome them, is now commonly represented as the zig-zag-zig model (Jones and Dangl 2006; Nishimura and Dangl 2010).

If a pathogen is to undergo a successful compatible interaction, it must overcome the constitutive barriers, avoid or suppress the immune responses, and reprogram the host cell for the establishment of infectious structures during penetration, invasion, and reproduction. Several recent reviews have dealt with the suppression of host defenses by bacterial, oomycete, and fungal pathogens (Birch et al. 2009; Ellis et al. 2009; Hein et al. 2009; Mansfield 2009; Schornack et al. 2009). We focus here on plant susceptibility and on those processes that are subverted by filamentous fungal and oomycete pathogens to promote disease. When appropriate, we provide examples of the manipulation of the host by bacterial pathogens.

\section{The boundary between out and in.}

Topography and chemical composition of the plant surface as well as the function and distribution of pores used by plants for gas exchange frequently determine infection processes. Several filamentous fungal and oomycete pathogens enter plant tissues by means of specialized penetration structures called appressoria. These structures enable the pathogen to breach the outer barrier (Judelson et al. 2008; Wilson and Talbot 2009). Appressorium formation by Colletotrichum trifolii, the causal agent of alfalfa anthracnose, requires the activity of a fungal protein kinase. Components of the plant cuticle activate the transcription of the gene encoding this kinase, thereby stimulating appressorium formation and penetration (Dickmann et al. 2003). The plant cuticle also determines infection by rust fungi. Germinating spores require a highly hydrophobic surface for adhesion, and the composition and amount of waxy compounds in the cuticle determines rust infection (Staples et al. 1985). Directed growth of germ tubes is then determined by the topography of the cuticle. Rust fungi detect ridges on the surface that match the dimensions of the stomatal lips of the host (Allen et al. 1991). Rusts are specific to this topography and are unable to locate stomata on nonhost plants (Kolmer et al. 2009). When a stoma is localized, the germ tube forms an appressorium over it and pushes through the stoma with a penetration peg.

The possibility that rust fungi interfere with stomatal functions to promote opening has not been explored, but some specialized fungi and bacteria secrete toxins or effectors that inter- 
act with host compounds, thus stimulating opening of stomata and favoring infection. Some of the toxins involved in such interactions had already been identified in the 1960s and 1970s. Several phytopathogenic fungi, such as Sclerotinia sclerotiorum, produce oxalic acid during the infection process (Bateman and Beer 1965), and mutants unable to synthesize this compound are less pathogenic than the wild-type fungus (Godoy et al. 1990). On the host plant of S. sclerotiorum, bean, secreted oxalic acid induces $\mathrm{K}^{+}$accumulation and the breakdown of starch in guard cells, effects that trigger stomatal opening. Additionally, oxalic acid inhibits abscissic acid (ABA)-induced stomatal closure. Stomata of Sclerotinia spp.-infected plants are blocked open and favor fungal development (Guimarães and Stotz 2004). Another well known toxin is the terpenoid fusicoccin A, which is produced by the fungus Fusicoccum amygdali, a parasite of peach and almond trees (Turner and Graniti 1969). This toxin binds to the $\mathrm{C}$-terminal domains of $\mathrm{H}^{+}$-ATPase dimers and requires a plant $14-3-3$ protein for full activity. It activates the $\mathrm{H}^{+}$-ATPase by stabilizing a transient complex that forms between the autoinhibitory C-terminal domain and the 14-3-3 dimer, thus locking the enzyme into its most active state, inducing hyperpolarization of the plasma membrane and the opening of stomata (Baunsgaard et al. 1998; MacRobbie and Smyth 2010; Oecking and Hagemann 1999; Oecking et al. 1997; Würtele et al. 2003).

More is known about the manipulation of stomatal opening by the bacterial pathogen, Pseudomonas syringae. The Arabidopsis protein RIN4 is guarded by $R$ gene products that confer immunity to $P$. syringae pathovars (Grant et al. 2006). RIN4 interacts with autoinhibitory $\mathrm{C}$-terminal $\mathrm{H}^{+}$-ATPase domains in guard cells (J. Liu et al. 2009). In contrast to the mode of action of fusicoccin, the binding of RIN4 to the $\mathrm{H}^{+}$-ATPase results in stomatal closure and is thought to be part of the array of MAMP-triggered immune responses for preventing pathogen entry. However, RIN4 is the target of Pseudomonas syringae effector proteins AvrRpm1, AvrB, AvrRpt2, and HopF2Pto (Wilton et al. 2010). The effector-mediated inactivation or degradation of RIN4 may enable the bacterium to prevent stomatal closure, thereby facilitating its entry into plant tissues (J. Liu et al. 2009). Furthermore, $P$. syringae produces the toxin coronatine, a structural analog of the jasmonate (JA) conjugate JAisoleucine (Melotto et al. 2008). Coronatine, by mimicking JA, is able to interact with the JA sensor CORONATINE INSENSITIVE1 (COI1). This interaction blocks guard cell-specific OST1 kinase and ABA signaling and prevents stomatal closure (Melotto et al. 2006). Thus, both fungal and bacterial pathogens manipulate stomata during the infection process.

\section{Cozy biotrophy.}

Filamentous biotrophs develop and multiply within living tissues, maintaining a delicate balance between extracting sufficient resources from host cells to complete their life cycle and leaving the plant with sufficient resources to ensure its survival. Haustoria are responsible for ensuring the maintenance of this balance and for the uptake of nutrients during growth and reproduction and are supposed to be the central structure for host manipulation during biotrophic growth (Fig. 1A). Pathogens must degrade the host cell wall locally to establish intracellular haustoria and to gain access to the nutrients present in the host. However, plants closely monitor the integrity of their cell walls and any damage leads to the activation of complex signaling networks, which are frequently interconnected with defense responses (Hématy et al. 2009). Filamentous biotrophs must thus minimize cell-wall degradation when forming their haustoria, to prevent the host from sensing the damage. Pathogens may achieve this by making use of the plant cell's own enzymatic machinery, thus loosening the cell wall to facilitate penetration without giving the impression of damage. Although clear experimental proofs for this hypothesis are yet lacking, several findings support it. A genetic screen aiming at identifying powdery mildew resistant ( $p m r$ ) mutants of Arabidopsis led to the identification of genes encoding a pectate lyase (PMR6), a callose synthase (PMR4), and a protein of unknown function (PMR5) (Vogel and Somerville 2000; Vogel et al. 2002, 2004). The corresponding mutants are more resistant than the wild type to infection with the fungus Golovinomyces cichoracearum. pmr6 and pmr5 mutants have cell walls with an altered pectin composition, which might interfere with the establishment of biotrophy. In addition, the pectate lyase PMR6 may be recruited by the fungus to prevent the accumulation of pectin in the extrahaustorial matrix (Fig. 1B) (Vogel et al. 2004). According to this hypothesis, the loss of PMR6 in the mutant decreases the availability of nutrients to the pathogen, resulting in the observed enhanced resistance phenotype (Vogel et al. 2002). The third mutant pmr4 shows enhanced resistance to both the fungal and oomycete biotrophs $G$. cichoracearum and Hyaloperonospora arabidopsidis, respectively (Vogel and Somerville 2000). PMR4 is a callose synthase that probably has multiple functions in susceptibility to the diseases caused by these pathogens. First, it has been shown that this enzyme or its product decreases salicylic acid (SA) signaling in Arabidopsis, thus amplifying SA-dependent defense responses in the pmr4 mutant upon infection (Jacobs et al. 2003; Nimishura et al. 2003). Second, callose deposition at the haustorial neck may be a structural requirement for the stability and function of this feeding structure (Jacobs et al. 2003) (Fig. 1C). The synthesis of callose and its deposition at wounds and infection sites are generally considered to be a characteristic plant defense response (Chen and Kim 2009). Filamentous biotrophs thus seem to manipulate host enzymes to promote haustorium formation and function and to subvert resistance mechanisms to favor infection.

Whole-genome transcript profiling is a powerful approach to the characterization of metabolic host reprogramming by filamentous biotrophs (Chandran et al. 2009; Doehlemann et al. 2008; Fabro et al. 2008; Skibbe et al. 2010; Van Esse et al. 2008). A microarray analysis of the Arabidopsis transcriptome during the invasive growth of $H$. arabidopsidis within leaf tissues led to the identification of 17 genes specifically induced in these conditions (Huibers et al. 2009). Most of these genes had previously been described as involved in stress responses. Their role in downy mildew susceptibility is not clear, but they may serve as targets for fungal effector proteins (Huibers et al. 2009). A more precise analysis of the Arabidopsis susceptibility transcriptome was recently performed on laser-dissected powdery mildew infection sites (Chandran et al. 2010). This analysis revealed that the fungus $G$. orontii induces complex genetic reprogramming of infected host cells, transforming them into metabolic sinks. Furthermore, data from the susceptibility transcriptome suggest that infection modulates the host cell cycle. MYB3R4 expression was found to be upregulated at sites of infection. This gene encodes a transcription factor that positively regulates $\mathrm{G}_{2} / \mathrm{M}$ progression and cytokinesis in Arabidopsis (Haga et al. 2007). Examination of the epidermal cells harboring haustoria and of the underlying mesophyll cells revealed increases in the size of the nuclei of these cells and in the quantity of 4',6-diamidino-2-phenylindole-stainable DNA. These changes were not observed in cells at some distance from the site of infection (Chandran et al. 2010). However, these cells do not divide, so cells at sites of infection probably undergo pathogen-induced endoreduplication. The loss-of-function $m y b 3 r 4$ mutation abolished endoreduplication at infection sites and increased resistance to G. orontii. It seems likely that the pathogen induces endoreduplication in host cells to increase 
gene copy number and metabolic capacity. As a result, the host can supply the fungus with more nutrients, facilitating its sustained growth and reproduction (Chandran et al. 2010).

\section{Clean-up and damage limitation.}

Pathogens frequently encounter toxic compounds that are produced by the host. Oat roots produce the antimicrobial triterpene glycoside avenacin. The infection of oat by the fungus Gaeumannomyces graminis var. avenae is dependent on the detoxification of this compound by a fungal avenacin hydrolase (Morrissey and Osbourn 1999). Similarly, the infection of tomato by the leaf spot fungus Septoria lycopersici depends on the production of tomatinase, an extracellular enzyme that hydrolyzes the steroidal glycoalkaloid $\alpha$-tomatine to the less toxic $\beta_{2}$-tomatine (Pareja-Jaime et al. 2008). However, $\beta_{2^{-}}$ tomatine also suppresses plant defense responses, and fungal tomatinase clearly plays a dual role in saponin detoxification and counteracting disease-resistance processes (Bouarab et al. 2002). The fungal pathogen thus subverts the preformed antimicrobial compounds of its host, making use of these compounds to facilitate the establishment of infection.

A genetic screen led to the identification of Arabidopsis mutants, which show enhanced resistance to disease caused by the oomycete $H$. arabidopsidis (Van Damme et al. 2005, 2008). One of these downy mildew resistant mutants, $d m r l$, is affected in a gene encoding a homoserine kinase, suggesting that this enzyme is required for full oomycete susceptibility. The precise role of this homoserine kinase in the promotion of disease remains unclear, but its substrate, homoserine, is a potent stimulator of plant resistance (Van Damme et al. 2009). H. arabi-

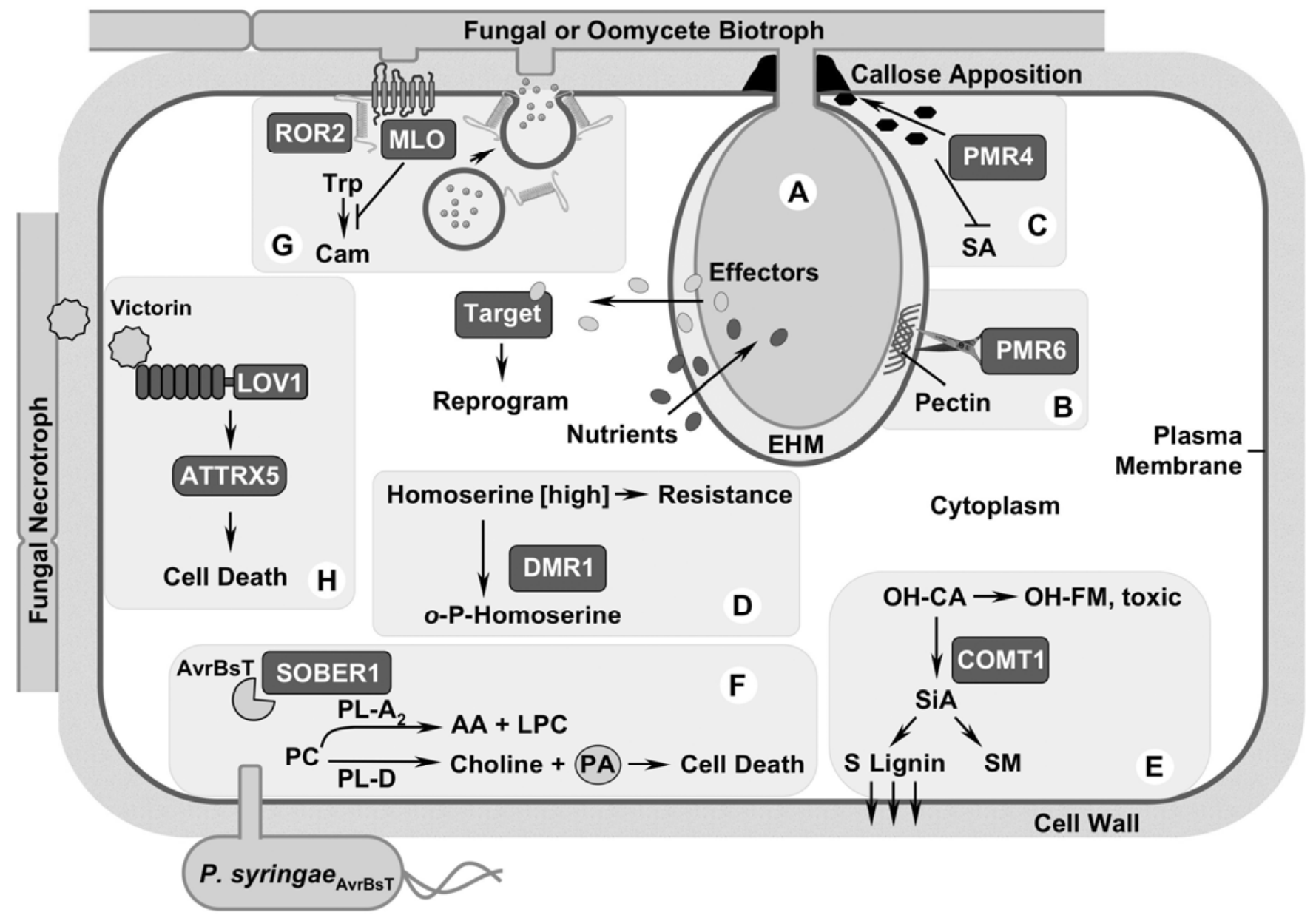

Fig. 1. Suggested functions for plant 'susceptibility gene' products. A, The haustorium delivers effectors into the plant cell. Their interaction with host targets reprograms the plant cell into a metabolic sink, thus favoring nutrient uptake (Chandran et al. 2010) and probably promoting the creation of a beneficial environment for the haustorium. B, The pectate lyase PMR6 is probably required to prevent pectin accumulation in the extrahaustorial matrix (EHM), thus facilitating the unrestricted translocation of effectors and nutrients (Vogel et al. 2002). C, The callose synthase PMR4 is required to repress the salicylic acid (SA)mediated resistance responses of the host. Callose deposition around the neck of the haustorium may stabilize this structure (Jacobs et al. 2003; Nishimura et al. 2003). D, The homoserine kinase DMR1 is thought to phosphorylate homoserine, decreasing its availability, thereby preventing the induction of resistance (Van Damme et al. 2009). E, The caffeate $O$-methyltransferase COMT1 transforms 5-hydroxy coniferaldehyde (OH-CA) into sinapaldehyde (SiA), a precurser of S lignin, which is incorporated into cell walls. Excess S lignin precursors are stored as inoffensive sinapoylmalate (SM). COMT1 activity may prevent the accumulation of 5-hydroxy feruloylmalate (OH-FM), which affects oomycete development (Quentin et al. 2009). F, To prevent the accumulation of harmful compounds, the bacterial pathogen P. syringae targets the phospholipase $\mathrm{A}_{2}$ (PL- $\mathrm{A}_{2}$ ) SOBER1, which hydrolyzes phosphatidylcholine (PC) into arachidonic acid (AA) and lysophosphatidylcholine (LPC). PC is also a substrate for phospholipase D (PL-D), hydrolyzing it into choline and phosphatidic acid (PA). High PA concentrations induce cell death, and depleting the pool of available PC by SOBER1 probably prevents PA generation (Kirik and Mudgett, 2009). G, MLO interacts with the syntaxin ROR2/PEN1. Adapted fungal biotrophs may use the MLO-mediated vesicle transport machinery to deliver plant proteins for the establishment of a compatible interaction. The vesicles probably also contribute to the extension of the plasma membrane during haustorium formation (Panstruga 2005). Additionally, MLO represses the tryptophan (Trp)-derived synthesis of harmful indolic compounds such as the phytoalexin camalexin (Cam) (Consonni et al. 2010). H, Fungal necrotrophs stimulate cell death. The toxin victorin targets the resistance gene product-like nucleotide binding site-leucine rich repeat protein, LOV1 (Sweat et al. 2008). LOV1 signals through the thioredoxin ATTRX5, which upregulates cell death, thereby probably promoting necrotrophic growth (Sweat and Wolpert, 2007). 
dopsidis may thus activate $D M R I$ expression and make use of this enzyme to prevent the accumulation of homoserine, which would counteract the infection process (Fig. 1D). Similarly, $H$. arabidopsidis stimulates the transcription of a gene encoding caffeic acid $O$-methyltransferase 1 (COMT1). Arabidopsis comt 1 mutants cannot synthesize precursors for the generation of $\mathrm{S}$ lignin to be incorporated into the cell wall. Instead, they accumulate soluble hydroxyferuloyl malate, a metabolite that interferes with normal oomycete development. The stimulation of COMT1 transcription may thus enable the oomycete to prevent the accumulation of a substance that would be harmful to it within plant tissues (Quentin et al. 2009) (Fig. 1E).

Again, more detailed information concerning the way in which host enzymes are manipulated to prevent the accumulation of substances counteracting infection is available for bacterial pathosystems. Pi- 0 is the only ecotype of $A$. thaliana that is resistant to $P$. syringae pv. tomato, which expresses the AvrBsT effector. This ecotype presents typical symptoms of the HR on infection with this bacterium. Crosses of Pi-0 with susceptible ecotypes revealed that resistance is associated with the loss-of-function of a gene encoding an $\alpha / \beta$ hydrolase called SUPPRESSOR OF AVRBST-ELICITED RESISTANCE 1 (SOBER1) (Cunnac et al. 2007). SOBER1 has phospholipase $\mathrm{A}_{2}$ activity and hydrolyzes phosphatidylcholine. In response to infection with $P$. syringae AvrBsT $_{\text {, }}$, only resistant Pi-0 plants accumulate high levels of phosphatidic acid (PA), suggesting that the HR of Pi-0 involves PA (Kirik and Mudgett 2009). Expression of the gene encoding SOBER1 in the Pi-0 background results in lower levels of PA production upon infection with $P$. syringae $_{\mathrm{AvrBsT}}$, preventing the $\mathrm{HR}$ and restoring susceptibility. In plant cells, PA is generated by the hydrolysis of phosphatidylcholine by phospholipase D. The role of SOBER1 may be to repress PA accumulation in infected plant cells by hydrolyzing phosphatidylcholine to generate inoffensive degradation products, thus decreasing its availability to phospholipase D. The SOBER1 lipase is, therefore, a negative regulator of AvrBsT-triggered PA signaling in Arabidopsis (Fig. 1F). These examples illustrate how oomycete and bacterial pathogens manipulate host enzymes in impede the production of substances that might interfere with the infection cycle.

\section{Resist or accommodate.}

If a host protein is required for the growth, multiplication, and reproduction of a pathogen within plant tissues, its absence or inaccessibility leads to recessively inherited resistance. Barley (Hordeum vulgare) harbors the mildew resistance locus Mlo. Wild-type barley carrying the Mlo gene is susceptible to the barley powdery mildew pathogen, Blumeria graminis f. sp. hordei. By contrast, recessive mutations in the gene confer durable resistance to all races of the fungus (Büschges et al. 1997; Piffanelli et al. 2004). Mutated mlo alleles were incorporated into barley during the early stages of domestication and have since been widely adopted in breeding programs (Jørgensen 1992). Mlo encodes an integral membrane protein with seven membrane-spanning helices, harboring a C-terminal calmodulin-binding domain. It interacts with ROR2, a SNARE domaincontaining syntaxin (Devoto et al. 1999, 2003; Kim et al. 2002). MLO and ROR2 accumulate in the plasma membrane at the sites of fungal penetration (Collins et al. 2003). The precise role of MLO in powdery mildew susceptibility remains unclear. However, SNARE proteins participate in the fusion of intracellular vesicles with the plasma membrane. MLO is, therefore, probably involved in the exocytosis of plant proteins and of compounds required for the formation of the haustorium (Fig. 1G). In Arabidopsis, three Mlo orthologs contribute to susceptibility to $G$. orontii. The mutation of one of these genes greatly decreases infection levels, and triple mutants are fully resistant
(Consonni et al. 2006). The spontaneous deposition of callose in these mutants in the absence of the pathogen suggests that MLO may downregulate basal defense mechanisms. Recently, it was shown that mlo2 and the mlo triple mutants are altered in metabolic steady-state levels of indolic compounds such as the phytoalexin camalexin and indolic glucosinolates (Consonni et al. 2010). These findings suggest that MLO negatively regulates the synthesis of tryptophan-derived indolic compounds that interfere with the infection process (Fig. 1G). MLO thus seem to orchestrate a complex susceptibility mechanism that has been conserved since the separation of the monocot and dicot lineages 200 million years ago (Consonni et al. 2006).

\section{Assisted host suicide.}

Necrotrophic ascomycetes from the order Pleosporales produce host-selective toxins (HST) that interact with specific targets within hosts plants to promote disease. Absence of HST production by the pathogen or absence (or inaccessibility) of the target in the host results in resistance (Friesen et al. 2008; Turgeon and Baker 2007; Wolpert et al. 2002). Genes encoding HST targets may therefore be considered recessive $R$ genes. For example, Stagonospora nodorum produces the HST protein SnTox3, which interacts directly or indirectly with the product of the corresponding wheat susceptibility gene Snn3 (Z. Liu et al. 2009). The helminthosporiosis pathogen of wheat, Pyrenophora tritici-repentis, produces the HST PtrToxA, which interacts with the host chloroplast protein ToxABP1 (Manning et al. 2007). In the chloroplast, this interaction interferes with the functioning of photosystems I and II, leading to a light-dependent accumulation of reactive oxygen species and necrosis, thus favoring the necrotrophic invasive growth of the fungus (Manning et al. 2009). Cochliobolus victoriae makes use of a subtle necrotrophic infection strategy based on the subversion of resistance responses. In its host, oat, only genotypes carrying the dominant $\mathrm{Vb}$ allele are susceptible to both the Victoria blight pathogen and the HST victorin (Wolpert and Macko 1989). Victorin secretion is essential for pathogenicity, indicating that this toxin promotes disease by targeting $\mathrm{Vb}$. In Arabidopsis, sensitivity to victorin is conferred by LOCUS ORCHESTRATING VICTORIN EFFECTS 1 (LOVI). This gene encodes a nucleotide binding site-leucine rich repeat protein resembling typical $R$ gene products (Lorang et al. 2004, 2007; Sweat et al. 2008). In Arabidopsis, LOV1 signals through the thioredoxin ATTRX5, which upregulates victorin-induced cell death (Sweat and Wolpert 2007) (Fig. 1H). It thus seems likely that victorin subverts an ancient $R$ gene-mediated immune response to provoke HR-like cell death and to promote necrotrophic infection.

\section{Molecular manipulators.}

Most of our recently acquired knowledge on the manipulation of the host by plant pathogens concerns the suppression of plant defenses and the counteracting of plant immune responses. However, the finding that filamentous necrotrophs target proteins resembling $R$ gene products suggests that pathogens with this lifestyle may turn immune responses to their own advantage rather than suppressing them. The borders between resistance and susceptibility are often blurred, and the examples presented above illustrate the ways in which pathogens may highjack certain elements of defense responses to favor disease. For filamentous hemibiotrophs such as Phytophthora infestans, the oomycete responsible for the Irish famine, a sequential infection strategy has been proposed, in which biotrophy is conditioned by the initial suppression of defenses, with the activation of HR-like responses coordinating the switch to necrotrophy (Kelley et al. 2010). The fine-tuning of host cell responses during Phytophthora infection is thought to be coordinated by 
effector proteins, which have an N-terminal RXLR-dEER motif directing their translocation into the host cell (Jiang et al. 2008; Rehmany et al. 2005; Whisson et al. 2007). The mechanisms of RXLR-effector translocation remain unclear, but this motif resembles the RXLXE/Q/D core motif used by the malaria pathogen Plasmodium falciparum to translocate effector proteins into the cytoplasm of human erythrocytes (Hiller et al. 2004; Marti et al. 2004). The recent $P$. infestans genome sequencing project showed this microbe to contain 563 genes encoding putative RXLR effectors (Haas et al. 2009), more than 300 of which were also found in other sequenced Phytophthora species (Tyler et al. 2006). In contrast to the situation for oomycete effectors, no clear consensus signature has yet been identified in fungal effectors. However, fungal biotrophs and hemibiotrophs such as oomycetes are thought to produce hundreds of effectors (De Wit et al. 2009). Haustoria, which are formed during biotrophic growth, may act as a reservoir for effector delivery directly into the host cell (Birch et al. 2009; Catanzariti et al. 2006) (Fig. 1A). One of the challenges facing us in the future is increasing our knowledge of i) the mechanisms and the timing of effector delivery into the host cell, ii) the identity of effector targets within the plant cell, iii) the physiological role of these targets in the absence of infection, and iv) the effector-mediated subversion of this role to favor disease.

\section{Concluding remarks.}

The analysis of host-cell genetic reprogramming by pathogens has excited considerable interest in recent years. However, detailed descriptions of the mechanisms underlying pathogen accommodation have essentially been provided by studies of Arabidopsis and bacterial pathogens. In contrast, we still know little about the manipulation of the host plant by filamentous biotrophs or hemibiotrophs, and most suggestions remain hypothetical. This is principally because the genetic analysis of biotrophy and hemibiotrophy is feasible for only a few pathosystems involving Arabidopsis, and filamentous biotrophs are not very amenable to functional genomics approaches. The establishment of models of compatible interactions between $A$. thaliana and fungal (O'Connell et al. 2004; Park et al. 2009) or oomycete pathogens (Attard et al. 2010) should help to fill the gaps that currently exist. Furthermore, genomic data for most of the pathogens involved have begun to accumulate in recent years. Tools and methods for functional genomics studies of fungal and oomycete pathogens are now well established and should increase our understanding of compatibility mechanisms in the future. Improvements in our knowledge of compatibility will, in turn, probably deepen our insight into both molecular phytopathology and plant physiology.

\section{ACKNOWLEDGMENTS}

Due to space constraints, we have inevitably had to omit the work of some of our colleagues from this review, and we apologize for these necessary omissions. This work was financially supported by INRA and the French Ministry for Education, Research, and Technology.

\section{LITERATURE CITED}

Allen, E. A., Hazen, B. E., Hoch, H. C., Kwon, Y., Leinhos, G. M. E., Staples, R. C., Stumpf, M. A., and Terhume, B. T. 1991. Appressorium formation in response to topographical signals by 27 rust species. Phytopathology 81:323-331.

Attard, A., Gourgues, M., Callemeyn-Torre, N., and Keller, H. 2010. The immediate activation of defense responses in Arabidopsis roots is not sufficient to prevent Phytophthora parasitica infection. New Phytol. 187:449-460

Bateman, D. F., and Beer, S. V. 1965. Simultaneous production and synergistic action of oxalic acid and polygalacturonase during pathogenesis of Sclerotium rolfsii. Phytopathology 55:204-211.
Baunsgaard, L., Fuglsang, A. T., Jahn, T., Korthout, H. A., de Boer, A. H., and Palmgren, M. G. 1998. The 14-3-3 proteins associate with the plant plasma membrane $\mathrm{H}(+)$-ATPase to generate a fusicoccin binding complex and a fusicoccin responsive system. Plant J. 13:661-671.

Birch, P. R., Armstrong, M., Bos, J., Boevink, P., Gilroy, E. M., Taylor, R. M., Wawra, S., Pritchard, L., Conti, L., Ewan, R., Whisson, S.C., van West, P., Sadanandom, A., and Kamoun, S. 2009. Towards understanding the virulence functions of RXLR effectors of the oomycete plant pathogen Phytophthora infestans. J. Exp. Bot. 60:1133-1140.

Bouarab, K., Melton, R., Peart, J., Baulcombe, D., and Osbourn, A. 2002. A saponin-detoxifying enzyme mediates suppression of plant defences. Nature 418:889-892.

Büschges, R., Hollricher, K., Panstruga, R., Simons, G., Wolter, M., Frijters, A., van Daelen, R., van der Lee, T., Diergaarde, P., Groenendijk, J., Töpsch, S., Vos, P., Salamini, F., and Schulze-Lefert, P. 1997. The barley Mlo gene: A novel control element of plant pathogen resistance. Cell 88:695-705.

Catanzariti, A. M., Dodds, P. N., Lawrence, G. J., Ayliffe, M. A., and Ellis, J. G. 2006. Haustorially expressed secreted proteins from flax rust are highly enriched for avirulence elicitors. Plant Cell 18:243-256.

Chandran, D., Tai, Y. C., Hather, G., Dewdney, J., Denoux, C., Burgess, D. G., Ausubel, F. M., Speed, T. P., and Wildermuth, M. C. 2009. Temporal global expression data reveal known and novel salicylate-impacted processes and regulators mediating powdery mildew growth and reproduction on Arabidopsis. Plant Physiol. 149:1435-1451.

Chandran, D., Inada, N., Hather, G., Kleindt, C. K., and Wildermuth, M. C. 2010. Laser microdissection of Arabidopsis cells at the powdery mildew infection site reveals site-specific processes and regulators. Proc. Natl. Acad. Sci. U.S.A. 107:460-465.

Chen, X. Y., and Kim, J. Y. 2009. Callose synthesis in higher plants. Plant Signal. Behav. 4:489-492.

Chisholm, S. T., Coaker, G., Day, B., and Staskawicz, B. J. 2006. Host-microbe interactions: Shaping the evolution of the plant immune response. Cell 124:803-814.

Collins, N. C., Thordal-Christensen, H., Lipka, V., Bau, S., Kombrink, E. Qiu, J. L., Hückelhoven, R., Stein, M., Freialdenhoven, A., Somerville, S.C., and Schulze-Lefert, P. 2003. SNARE-protein-mediated disease resistance at the plant cell wall. Nature 425:973-977.

Consonni, C., Humphry, M. E., Hartmann, H. A., Livaja, M., Durner, J., Westphal, L., Vogel, J., Lipka, V., Kemmerling, B., Schulze-Lefert, P., Somerville, S. C., and Panstruga, R. 2006. Conserved requirement for a plant host cell protein in powdery mildew pathogenesis. Nat. Genet. 38:716-720.

Consonni, C., Bednarek, P., Humphry, M., Francocci, F., Ferrari, S., Harzen, A., Ver Loren van Themaat, E., and Panstruga, R. 2010. Tryptophanderived metabolites are required for antifungal defense in the Arabidopsis mlo2 mutant. Plant Physiol. 152:1544-1561.

Cunnac, S., Wilson, A., Nuwer, J., Kirik, A., Baranage, G., and Mudgett, M. B. 2007. A conserved carboxylesterase is a SUPPRESSOR OF AVRBST-ELICITED RESISTANCE in Arabidopsis. Plant Cell 19:688705.

De Wit, P. J., Mehrabi, R., Van den Burg, H. A., and Stergiopoulos, I. 2009. Fungal effector proteins: Past, present and future. Mol. Plant Pathol. 10:735-747.

Devoto, A., Piffanelli, P., Nilsson, I., Wallin, E., Panstruga, R., von Heijne, G., and Schulze-Lefert, P. 1999. Topology, subcellular localization, and sequence diversity of the Mlo family in plants. J. Biol. Chem. 274:34993-35004.

Devoto, A., Hartmann, H. A., Piffanelli, P., Elliott, C., Simmons, C., Taramino, G., Goh, C. S., Cohen, F. E., Emerson, B. C., Schulze-Lefert, P., and Panstruga, R. 2003. Molecular phylogeny and evolution of the plant-specific seven-transmembrane MLO family. J. Mol. Evol. 56:7788.

Dickman, M. B., Ha, Y.-S., Yang, Z., Adams, B., and Huang, C. 2003. A protein kinase from Colletotrichum trifolii is induced by plant cutin and is required for appressorium formation. Mol. Plant-Microbe Interact. $16: 411-421$.

Doehlemann, G., Wahl, R., Horst, R. J., Voll, L. M., Usadel, B., Poree, F. Stitt, M., Pons-Kühnemann, J., Sonnewald, U., Kahmann, R., and Kämper, J. 2008. Reprogramming a maize plant: Transcriptional and metabolic changes induced by the fungal biotroph Ustilago maydis. Plant J. 56:181-195.

Ellis, J. G., Rafiqi, M., Gan, P., Chakrabarti, A., and Dodds, P. N. 2009. Recent progress in discovery and functional analysis of effector proteins of fungal and oomycete plant pathogens. Curr. Opin. Plant Biol. 12:399-405.

Fabro, G., Di Rienzo, J. A., Voigt, C. A., Savchenko, T., Dehesh, K., Somerville, S., and Alvarez, M. E. 2008. Genome-wide expression profiling Arabidopsis at the stage of Golovinomyces cichoracearum haustorium formation. Plant Physiol. 146:1421-1439. 
Friesen, T. L., Faris, J. D., Solomon, P. S., and Oliver, R.P. 2008. Host-specific toxins: Effectors of necrotrophic pathogenicity. Cell. Microbiol. 10:1421-1428.

Godoy, G., Steadman, J. R., Dickman, M. B., and Dam, R. 1990. Use of mutants to demonstrate the role of oxalic acid in pathogenicity of Sclerotinia sclerotiorum on Phaseolus vulgaris. Physiol. Mol. Plant Pathol. 37:179-191.

Grant, S. R., Fisher, E. J., Chang, J. H., Mole, B. M., and Dangl, J. L. 2006. Subterfuge and manipulation: Type III effector proteins of phytopathogenic bacteria. Annu. Rev. Microbiol. 60:425-449.

Guimarães, R. L., and Stotz, H. U. 2004. Oxalate production by Sclerotinia sclerotiorum deregulates guard cells during infection. Plant Physiol. 136:3703-3711.

Haas, B. J., Kamoun, S., Zody, M. C., Jiang, R. H., Handsaker, R. E., Cano, L. M., Grabherr, M., Kodira, C. D., Raffaele, S., Torto-Alalibo, T., Bozkurt, T. O., Ah-Fong, A. M., Alvarado, L., Anderson, V. L., Armstrong, M. R., Avrova. A., Baxter, L., Beynon, J., Boevink, P. C., Bollmann, S. R., Bos, J. I., Bulone, V., Cai, G., Cakir, C., Carrington, J. C., Chawner, M., Conti, L., Costanzo, S., Ewan, R., Fahlgren, N., Fischbach, M. A., Fugelstad, J., Gilroy, E. M., Gnerre, S., Green, P. J., Grenville-Briggs, L. J., Griffith, J., Grünwald, N. J., Horn, K., Horner, N. R., Hu, C. H., Huitema, E., Jeong, D. H., Jones, A. M., Jones, J. D., Jones, R. W., Karlsson, E. K., Kunjeti, S. G., Lamour, K., Liu, Z., Ma, L., Maclean, D., Chibucos, M. C., McDonald, H., McWalters, J., Meijer, H. J., Morgan, W., Morris, P. F., Munro, C. A., O'Neill, K., Ospina-Giraldo, M., Pinzón, A., Pritchard, L., Ramsahoye, B., Ren, Q., Restrepo, S., Roy, S., Sadanandom, A., Savidor, A., Schornack, S., Schwartz, D. C., Schumann, U. D., Schwessinger, B., Seyer, L., Sharpe, T., Silvar, C., Song, J., Studholme, D. J., Sykes, S., Thines, M., van de Vondervoort, P. J., Phuntumart, V., Wawra, S., Weide, R., Win, J., Young, C., Zhou, S., Fry, W., Meyers, B. C., van West, P., Ristaino, J., Govers, F., Birch, P. R., Whisson, S. C., Judelson, H. S., and Nusbaum, C. 2009. Genome sequence and analysis of the Irish potato famine pathogen Phytophthora infestans. Nature 461:393-398.

Haga, N., Kato, K., Murase, M., Araki, S., Kubo, M., Demura, T., Suzuki, K., Müller, I., Voss, U., Jürgens, G., and Ito, M. 2007. R1R2R3-Myb proteins positively regulate cytokinesis through activation of KNOLLE transcription in Arabidopsis thaliana. Development 134:1101-1110.

Hein, I., Gilroy, E. M., Armstrong, M. R., and Birch, P. R. 2009. The zigzag-zig in oomycete-plant interactions. Mol. Plant Pathol. 10:547-562.

Hématy, K., Cherk, C., and Somerville, S. 2009. Host-pathogen warfare at the plant cell wall. Curr. Opin. Plant Biol. 12:406-413.

Hiller, N. L., Bhattacharjee, S., van Ooij, C., Liolios, K., Harrison, T., Lopez-Estraño, C., and Haldar, K. 2004. A host-targeting signal in virulence proteins reveals a secretome in malarial infection. Science 306:1934-1937.

Huibers, R. P., de Jong, M., Dekter, R. W., and Van den Ackerveken, G. 2009. Disease-specific expression of host genes during downy mildew infection of Arabidopsis. Mol. Plant-Microbe Interact. 22:1104-1115.

Jacobs, A. K., Lipka, V., Burton, R. A., Panstruga, R., Strizhov, N., Schulze-Lefert, P., and Fincher, G. B. 2003. An Arabidopsis callose synthase, GSL5, is required for wound and papillary callose formation. Plant Cell 15:2503-2513.

Jiang, R. H., Tripathy, S., Govers, F., and Tyler, B. M. 2008. RXLR effector reservoir in two Phytophthora species is dominated by a single rapidly evolving super-family with more than 700 members. Proc. Natl. Acad. Sci. U.S.A. 105:4874-4879.

Jones, J. D., and Dangl, J. L. 2006. The plant immune system. Nature 444:323-329.

Jørgensen, J. H. 1992. Discovery, characterization and exploitation of Mlo powdery mildew resistance in barley. Euphytica 63:141-152.

Judelson, H. S., Ah-Fong, A. M. V., Aux, G., Avrova, A. O., Bruce, C., Cakir, C., da Cunha, L., Grenville-Briggs, L., Latijnhouwers, M., Ligterink, W., Meijer, H. J. G., Roberts, S., Thurber, C. S., Whisson, S. C., Birch, P. R. J., Govers, F., Kamoun, S., van West, P., and Windass, J. 2008. Gene expression profiling during asexual development of the late blight pathogen Phytophthora infestans reveals a highly dynamic transcriptome. Mol. Plant-Microbe Interact. 21:433-447.

Kelley, B. S., Lee, S. J., Damasceno, C. M., Chakravarthy, S., Kim, B. D., Martin, G. B., and Rose, J. K. 2010. A secreted effector protein (SNE1) from Phytophthora infestans is a broadly acting suppressor of programmed cell death. Plant J. 62:357-366.

Kim, M. C., Panstruga, R., Elliott, C., Müller, J., Devoto, A., Yoon, H. W., Park, H. C., Cho, M. J., and Schulze-Lefert, P. 2002. Calmodulin interacts with MLO protein to regulate defence against mildew in barley. Nature 416:447-451.

Kirik, A., and Mudgett, M. B. 2009. SOBER1 phospholipase activity suppresses phosphatidic acid accumulation and plant immunity in response to bacterial effector AvrBsT. Proc. Natl. Acad. Sci. U.S.A. 106:2053220537.
Kolmer, J. A., Ordonez, M. E., and Groth, J. V. 2009. The Rust Fungi. In: Encyclopedia of Life Sciences, John Wiley \& Sons Ltd, Chichester West Sussex, England.

Liu, J., Elmore, J. M., Fuglsang, A. T., Palmgren, M. G., Staskawicz, B. J., and Coaker, G. 2009. RIN4 functions with plasma membrane $\mathrm{H}^{+}$ ATPases to regulate stomatal apertures during pathogen attack. PLoS Biol. 7:e1000139. Published online.

Liu, Z., Faris, J. D., Oliver, R. P., Tan, K. C., Solomon, P. S., McDonald, M. C., McDonald, B. A., Nunez, A., Lu, S., Rasmussen, J. B., and Friesen, T. L. 2009. SnTox3 acts in effector triggered susceptibility to induce disease on wheat carrying the Snn3 gene. PLoS Pathog. 5:e1000581. Published online.

Lorang, J. M., Carkaci-Salli, N., and Wolpert, T.J. 2004. Identification and characterization of victorin sensitivity in Arabidopsis thaliana. Mol. Plant-Microbe Interact. 17:577-582.

Lorang, J. M., Sweat, T. A., and Wolpert, T. J. 2007. Plant disease susceptibility conferred by a "resistance" gene. Proc. Natl. Acad. Sci. U.S.A. 104:14861-14866.

MacRobbie, E. A., and Smyth, W. D. 2010. Effects of fusicoccin on ion fluxes in guard cells. New Phytol. 186:636-647.

Manning, V. A., Hardison, L. K., and Ciuffetti, L. M. 2007. Ptr ToxA interacts with a chloroplast-localized protein. Mol. Plant-Microbe Interact. 20:168-177.

Manning, V. A., Chu, A. L., Steeves, J. E., Wolpert, T. J., and Ciuffetti, L. M. 2009. A host-selective toxin of Pyrenophora tritici-repentis, Ptr ToxA, induces photosystem changes and reactive oxygen species accumulation in sensitive wheat. Mol. Plant-Microbe Interact. 22:665-676.

Mansfield, J.W. 2009. From bacterial avirulence genes to effector functions via the hrp delivery system: An overview of 25 years of progress in our understanding of plant innate immunity. Mol. Plant. Pathol. 10:721-734.

Marti, M., Good, R. T., Rug, M., Knuepfer, E., and Cowman, A. F. 2004 Targeting malaria virulence and remodeling proteins to the host erythrocyte. Science 306:1930-1933.

Melotto, M., Underwood, W., Koczan, J., Nomura, K., and He, S. Y. 2006. Plant stomata function in innate immunity against bacterial invasion. Cell 126:969-980.

Melotto, M., Underwood, W., and He, S. Y. 2008. Role of stomata in plant innate immunity and foliar bacterial diseases. Annu. Rev. Phytopathol. 46:101-122.

Morrissey, J. P. and, Osbourn, A. E. 1999. Fungal resistance to plant antibiotics as a mechanism of pathogenesis. Microbiol. Mol. Biol. Rev. 63:708-724.

Nishimura, M. T., and Dangl, J. L. 2010. Arabidopsis and the plant immune system. Plant J. 61:1053-1066.

Nishimura, M. T., Stein, M., Hou, B. H., Vogel, J. P., Edwards, H., and Somerville, S. C. 2003. Loss of a callose synthase results in salicylic acid-dependent disease resistance. Science 301:969-972.

O'Connell, R., Herbert, C., Sreenivasaprasad, S., Khatib, M., EsquerréTugayé, M.-T., and Dumas, B. 2004. A novel Arabidopsis-Colletotrichum pathosystem for the molecular dissection of plant-fungal interactions. Mol Plant-Microbe Interact. 17:272-282

Oecking, C., and Hagemann, K. 1999. Association of 14-3-3 proteins with the C-terminal auto-inhibitory domain of the plant plasma-membrane $\mathrm{H}^{+}$-ATPase generates a fusicoccin-binding complex. Planta 207:480482.

Oecking, C., Piotrowski, M., Hagemeier, J., and Hagemann, K. 1997. Topology and target interaction of the fusicoccin-binding 14-3-3 homologs of Commelina communis. Plant J. 12:441-453.

Panstruga, R. 2005. Serpentine plant MLO proteins as entry portals for powdery mildew fungi. Biochem. Soc. Trans. 33:389-392.

Pareja-Jaime, Y., Roncero, M. I., and Ruiz-Roldán, M. C. 2008. Tomatinase from Fusarium oxysporum f. sp. lycopersici is required for full virulence on tomato plants. Mol. Plant-Microbe Interact. 21:728-736.

Park, J. Y., Jin, J., Lee, Y. W., Kang, S., and Lee, Y. H. 2009. Rice blast fungus (Magnaporthe oryzae) infects Arabidopsis via a mechanism distinct from that required for the infection of rice. Plant Physiol. 149:474486.

Piffanelli, P., Ramsay, L., Waugh, R., Benabdelmouna, A., D'Hont, A., Hollricher, K., Jørgensen, J. H., Schulze-Lefert, P., and Panstruga, R. 2004. A barley cultivation-associated polymorphism conveys resistance to powdery mildew. Nature 430:887-891.

Quentin, M., Allasia, V., Pegard, A., Allais, F., Ducrot, P. H., Favery, B. Levis, C., Martinet, S., Masur, C., Ponchet, M., Roby, D., Schlaich, N. L., Jouanin, L., and Keller, H. 2009. Imbalanced lignin biosynthesis promotes the sexual reproduction of homothallic oomycete pathogens. PLoS Pathog. 5:e1000264. Published online.

Rehmany, A. P., Gordon, A., Rose, L. E., Allen, R. L., Armstrong, M. R. Whisson, S. C., Kamoun, S., Tyler, B. M., Birch, P. R, and Beynon, J. L. 2005. Differential recognition of highly divergent downy mildew 
avirulence gene alleles by $R P P 1$ resistance genes from two Arabidopsis lines. Plant Cell 17:1839-1850.

Schornack, S., Huitema, E., Cano, L. M., Bozkurt, T. O., Oliva, R., Van Damme, M., Schwizer, S., Raffaele, S., Chaparro-Garcia, A., Farrer, R., Segretin, M. E., Bos, J., Haas, B. J., Zody, M. C., Nusbaum, C., Win, J., Thines, M., and Kamoun, S. 2009.Ten things to know about oomycete effectors. Mol. Plant Pathol. 10:795-803.

Skibbe, D. S., Doehlemann, G., Fernandes, J., and Walbot, V. 2010. Maize tumors caused by Ustilago maydis require organ-specific genes in host and pathogen. Science 328:89-92.

Staples, R. C., Hoch, H. C., Epstein, L., Laccetti, L., and Hassouna, S 1985. Recognition of host morphology by rust fungi: Responses and mechanisms. Can. J. Plant Pathol. 7:314-322.

Sweat, T. A., and Wolpert, T. J. 2007. Thioredoxin h5 is required for victorin sensitivity mediated by a CC-NBS-LRR gene in Arabidopsis. Plant Cell 19:673-687.

Sweat, T. A., Lorang, J. M., Bakker, E. G., and Wolpert, T. J. 2008. Characterization of natural and induced variation in the LOVI gene, a CCNB-LRR gene conferring victorin sensitivity and disease susceptibility in Arabidopsis. Mol. Plant-Microbe Interact. 21:7-19.

Turgeon, B. G., and Baker, S. E. 2007. Genetic and genomic dissection of the Cochliobolus heterostrophus Tox 1 locus controlling biosynthesis of the polyketide virulence factor T-toxin. Adv. Genet. 57:219261

Turner, N. C., and Graniti, A. 1969. Fusicoccin: A fungal toxin that opens stomata. Nature 223:1070-1071.

Tyler, B. M., Tripathy, S., Zhang, X., Dehal, P., Jiang, R. H., Aerts, A., Arredondo, F. D., Baxter, L., Bensasson, D., Beynon, J. L., Chapman, J., Damasceno, C. M., Dorrance, A. E., Dou, D., Dickerman, A. W., Dubchak, I. L., Garbelotto, M., Gijzen, M., Gordon, S. G., Govers, F., Grunwald, N. J., Huang, W., Ivors, K. L., Jones, R. W., Kamoun, S. Krampis, K., Lamour, K. H., Lee, M. K., McDonald, W. H., Medina, M., Meijer, H. J., Nordberg, E. K., Maclean, D. J., Ospina-Giraldo, M. D., Morris, P. F., Phuntumart, V., Putnam, N. H., Rash, S., Rose, J. K., Sakihama, Y., Salamov, A. A., Savidor, A., Scheuring, C. F., Smith, B. M., Sobral, B. W., Terry, A., Torto-Alalibo, T. A., Win, J., Xu, Z., Zhang, H., Grigoriev, I. V., Rokhsar, D. S., and Boore, J. L. 2006. Phytophthora genome sequences uncover evolutionary origins and mechanisms of pathogenesis. Science 313:1261-1266.

Van Damme, M., Andel, A., Huibers, R. P., Panstruga, R., Weisbeek, P. J., and Van den Ackerveken, G. 2005. Identification of Arabidopsis loci required for susceptibility to the downy mildew pathogen Hyaloperonospora parasitica. Mol. Plant-Microbe Interact. 18:583-592.
Van Damme, M., Huibers, R. P., Elberse, J., and Van den Ackerveken, G. 2008. Arabidopsis DMR6 encodes a putative 2OG-Fe(II) oxygenase that is defense-associated but required for susceptibility to downy mildew. Plant J. 54:785-793.

Van Damme, M., Zeilmaker, T., Elberse, J., Andel, A., de Sain-van der Velden, M., and Van den Ackerveken, G. 2009. Downy mildew resistance in Arabidopsis by mutation of HOMOSERINE KINASE. Plant Cell 21:2179-2189.

Van Esse, H. P., Van't Klooster, J. W., Bolton, M. D., Yadeta, K. A., van Baarlen, P., Boeren, S., Vervoort, J., de Wit, P. J., and Thomma, B. P. 2008. The Cladosporium fulvum virulence protein Avr2 inhibits host proteases required for basal defense. Plant Cell 20:1948-1963.

Vogel, J., and Somerville, S. 2000. Isolation and characterization of powdery mildew-resistant Arabidopsis mutants. Proc. Natl. Acad. Sci. U.S.A. 97:1897-1902.

Vogel, J. P., Raab, T. K., Schiff, C., and Somerville, S. C. 2002. PMR6, a pectate lyase-like gene required for powdery mildew susceptibility in Arabidopsis. Plant Cell 14:2095-2106.

Vogel, J. P., Raab, T. K., Somerville, C. R., and Somerville, S. C. 2004. Mutations in PMR5 result in powdery mildew resistance and altered cell wall composition. Plant J. 40:968-978.

Whisson, S. C., Boevink, P. C., Moleleki, L., Avrova, A. O., Morales, J. G., Gilroy, E. M., Armstrong, M. R., Grouffaud, S., van West, P., Chapman, S., Hein, I., Toth, I. K., Pritchard, L., and Birch, P. R. 2007. A translocation signal for delivery of oomycete effector proteins into host plant cells. Nature 450:115-118.

Wilson, R. A., and Talbot, N. J. 2009. Under pressure: Investigating the biology of plant infection by Magnaporthe oryzae. Nat. Rev. Microbiol. 7:185-195.

Wilton, M., Subramaniam, R., Elmore, J., Felsensteiner, C., Coaker, G. and Desveaux, D. 2010. The type III effector HopF2Pto targets Arabidopsis RIN4 protein to promote Pseudomonas syringae virulence. Proc. Natl. Acad. Sci. U.S.A. 107:2349-2354.

Wolpert, T. J., and Macko, V. 1989. Specific binding of victorin to a 100kDa protein from oats.Proc. Natl. Acad. Sci. U.S.A. 86:4092-4096.

Wolpert, T. J., Dunkle, L. D., and Ciuffetti, L. M. 2002. Host-selective toxins and avirulence determinants: What's in a name? Annu. Rev. Phytopathol. 40:251-285.

Würtele, M., Jelich-Ottmann, C., Wittinghofer, A., and Oecking, C. 2003. Structural view of a fungal toxin acting on a 14-3-3 regulatory complex. EMBO J. 22:987-994.

Zipfel, C. 2009. Early molecular events in PAMP-triggered immunity. Curr. Opin. Plant Biol. 12:414-420. 